\title{
TRS-based PCR as a potential tool for inter-serovar discrimination of Salmonella Enteritidis, $S$. Typhimurium, $S$. Infantis, $S$. Virchow, $S$. Hadar, $S$. Newport and $S$. Anatum
}

\author{
Marta Majchrzak • Anna Krzyzanowska • Anna B. Kubiak • Arkadiusz Wojtasik • \\ Tomasz Wolkowicz · Jolanta Szych • Pawel Parniewski
}

Received: 13 March 2013/ Accepted: 7 July 2014/ Published online: 26 July 2014

(c) The Author(s) 2014. This article is published with open access at Springerlink.com

\begin{abstract}
Salmonella enterica subsp. enterica comprises a number of serovars, many of which pose an epidemiological threat to humans and are a worldwide cause of morbidity and mortality. Most reported food infection outbreaks involve the serovars Salmonella Enteritidis and Salmonella Typhimurium. Rapid identification to determine the primary sources of the bacterial contamination is important to the improvement of public health. In recent years, many DNA-based techniques have been applied to genotype Salmonella. Herein, we report the use of a manual TRS-PCR approach for the differentiation of the Salmonella enterica subspecies enterica serovars in a single-tube assay. One hundred seventy Salmonella strains were examined in this work. These consisted of serovars $S$. Enteritidis, $S$. Typhimurium, $S$. Infantis, $S$. Virchow, $S$. Hadar, $S$. Newport and $S$. Anatum. Five of the TRS-primers, $\mathrm{N}_{6}(\mathrm{GTG})_{4}, \mathrm{~N}_{6}(\mathrm{CAC})_{4}, \mathrm{~N}_{6}(\mathrm{CGG})_{4}, \mathrm{~N}_{6}(\mathrm{CCG})_{4}$ and $\mathrm{N}_{6}(\mathrm{CTG})_{4}$, perfectly distinguished the $S$. Enteritidis and $S$. Typhimurium serovars, and the $\mathrm{N}_{6}(\mathrm{GTG})_{4}$ primer additionally grouped the other five frequently isolated serovars. In our opinion, the TRS-PCR methodology could be recommended for a quick and simple DNA-based test for inter-serovar discrimination of Salmonella strains.
\end{abstract}

Keywords Salmonella enterica · TRS-PCR . Genotyping $\cdot$ Serovars

M. Majchrzak · A. Krzyzanowska · A. B. Kubiak ·

A. Wojtasik · P. Parniewski ( $₫)$

Institute of Medical Biology PAS, 106 Lodowa Street,

93-232 Lodz, Poland

e-mail: pparniewski@cbm.pan.pl

T. Wolkowicz $\cdot$ J. Szych

Department of Bacteriology, National Institute of Public Health -

National Institute of Hygiene, 24 Chocimska Street,

00-791 Warsaw, Poland

\section{Introduction}

Salmonella enterica subsp. enterica comprises a number of serovars, many of which pose epidemiological threats to humans worldwide. In the European Union, $S$. Enteritidis and $S$. Typhimurium are the most frequently reported serovars [1-3]. Human infections with serovar $S$. Enteritidis are predominately associated with the consumption of contaminated eggs and poultry meat, while $S$. Typhimurium cases are mostly associated with the consumption of contaminated pork, poultry and bovine meat [4]. Therefore, the European Commission has introduced the obligation to examine poultry for the appearance of $S$. Enteritidis and $S$. Typhimurium, according to which, during the entire period before expiration, there should be none of these serovars in a $25 \mathrm{~g}$ sample [5].

A wide range of other serovars, i.e., $S$. Infantis, $S$. Virchow, $S$. Hadar, $S$. Anatum, $S$. Newport, are commonly isolated in humans and also are of public health significance [1-3].

Salmonella isolates are currently phenotypically identified according to the White-Kauffmann-Le Minor scheme [6], even though this method is labor-intensive and expensive. In addition, several molecular typing methods have been developed and applied to distinguish $S$. enterica isolates. Pulsed-field gel electrophoresis (PFGE) is a "gold standard" among the subtyping methods used in Salmonella outbreak investigations [7]. Despite the undeniable advantage of employing the highly advanced molecular methods, the cost of equipment and need for skilled staff may exclude some methods from use in many countries that need them the most. That is why there is still a need for new methods that are simple, inexpensive and able to discriminate among Salmonella serotypes.

Together with our previous studies, this study shows the usefulness of the manual rep-PCR procedure based on the 
Table 1 Salmonella enterica subsp. enterica isolates used in this study

\begin{tabular}{|c|c|c|c|c|c|c|c|}
\hline Serovar & Isolate no. & Antigenic formulae & Patient ID & Sex/age & Origin & Collection date [d.m.y] & Place of isolation ID $^{\mathrm{a}}$ \\
\hline \multirow[t]{38}{*}{ Typhimurium } & S003 & \multirow[t]{38}{*}{$1,4[5], 12: \mathrm{i}: 1,2$} & 63 & $\mathrm{M} / 23 \mathrm{y}$ & stool & 20.02.2009 & 1 \\
\hline & S005 & & 1 & $\mathrm{M} / 30 \mathrm{y}$ & stool & 20.02 .2009 & 1 \\
\hline & S006 & & 2 & $\mathrm{~F} / 28 \mathrm{y}$ & stool & 18.03 .2009 & 1 \\
\hline & S013 & & 2 & $\mathrm{~F} / 28 \mathrm{y}$ & stool & 31.03.2009 & 1 \\
\hline & S048 & & 3 & $\mathrm{~F} / 20 \mathrm{~m}$ & stool & 27.08 .2009 & 1 \\
\hline & S050 & & 4 & M/6y & stool & 08.09 .2009 & 1 \\
\hline & S061 & & 5 & $\mathrm{M} / 25 \mathrm{~m}$ & stool & 29.09 .2009 & 1 \\
\hline & S062 & & 6 & $\mathrm{M} / 25 \mathrm{~m}$ & stool & 29.09 .2009 & 1 \\
\hline & S064 & & 7 & $\mathrm{~F} / 19 \mathrm{~m}$ & stool & 29.09 .2009 & 1 \\
\hline & S077 & & 8 & $\mathrm{~F} / 12 \mathrm{~m}$ & stool & 29.10.2009 & 1 \\
\hline & S111 & & $?$ & $?$ & stool & $(04.04 .2011)^{b}$ & 2 \\
\hline & S116 & & $?$ & $?$ & stool & $(04.04 .2011)$ & 2 \\
\hline & S117 & & $?$ & $?$ & stool & $(04.04 .2011)$ & 2 \\
\hline & S118 & & $?$ & $?$ & stool & $(04.04 .2011)$ & 2 \\
\hline & S119 & & $?$ & $?$ & stool & $(04.04 .2011)$ & 2 \\
\hline & $\mathrm{S} 121$ & & $?$ & $?$ & stool & $(04.04 .2011)$ & 2 \\
\hline & $\mathrm{S} 122$ & & $?$ & $?$ & stool & $(04.04 .2011)$ & 2 \\
\hline & $\mathrm{S} 123$ & & $?$ & $?$ & stool & $(04.04 .2011)$ & 2 \\
\hline & $\mathrm{S} 125$ & & NA & NA & food & $(10.04 .2012)$ & NA \\
\hline & S126 & & NA & NA & food & $(10.04 .2012)$ & 3 \\
\hline & S127 & & 66 & M/58y & stool & 22.02 .2012 & 4 \\
\hline & $\mathrm{S} 128$ & & 67 & $\mathrm{M} / 6$ & stool & 18.10 .2011 & 5 \\
\hline & $\mathrm{S} 129$ & & 68 & $\mathrm{~F} / 18 \mathrm{~m}$ & stool & 04.09 .2011 & 5 \\
\hline & $\mathrm{S} 130$ & & 69 & $\mathrm{~F} / 86$ & stool & 01.09 .2011 & 4 \\
\hline & $\mathrm{S} 131$ & & 70 & $\mathrm{M} / ?$ & stool & (13.09.2011) & 4 \\
\hline & $\mathrm{S} 132$ & & 71 & $\mathrm{~F} / 55$ & stool & 01.08 .2011 & 4 \\
\hline & $\mathrm{S} 133$ & & 72 & $\mathrm{M} / 42 \mathrm{~m}$ & stool & 06.08 .2011 & 4 \\
\hline & $\mathrm{S} 134$ & & NA & NA & food & $(23.03 .2011)$ & NA \\
\hline & $\mathrm{S} 135$ & & 73 & $\mathrm{M} / 42 \mathrm{~m}$ & stool & 15.11 .2010 & 5 \\
\hline & $\mathrm{S} 136$ & & NA & $\mathrm{NA}$ & RIVM & NA & NA \\
\hline & $\mathrm{S} 137$ & & NA & $\mathrm{NA}$ & food & $(05.11 .2010)$ & NA \\
\hline & $\mathrm{S} 138$ & & 74 & F/26y & blood & 15.09 .2010 & 6 \\
\hline & $\mathrm{S} 139$ & & 75 & $\mathrm{M} / 50 \mathrm{y}$ & blood & 07.09 .09 & 6 \\
\hline & $\mathrm{S} 140$ & & NA & NA & food & (13.10.10) & NA \\
\hline & $\mathrm{S} 141$ & & NA & NA & food & (13.10.2010) & NA \\
\hline & $\mathrm{S} 142$ & & $\mathrm{NA}$ & NA & food & (21.01.2010) & NA \\
\hline & S143 & & NA & NA & RIVM & NA & NA \\
\hline & $\mathrm{S} 144$ & & NA & $\mathrm{NA}$ & food & (17.11.2009) & NA \\
\hline \multirow[t]{10}{*}{ Infantis } & S004 & \multirow[t]{10}{*}{$6,7,14: r: 1,5$} & 9 & $\mathrm{M} / 20 \mathrm{~m}$ & stool & 20.02.2009 & 1 \\
\hline & S018 & & 10 & $\mathrm{~F} / 17 \mathrm{~m}$ & stool & 23.04 .2009 & 1 \\
\hline & S025 & & 11 & $\mathrm{M} / 8 \mathrm{~m}$ & stool & 14.05 .2009 & 1 \\
\hline & S054 & & 12 & $\mathrm{~F} / 7 \mathrm{~m}$ & stool & 08.09.2009 & 1 \\
\hline & $\mathrm{S} 100$ & & 13 & $?$ & stool & $(04.04 .2011)$ & 2 \\
\hline & $\mathrm{S} 145$ & & 76 & $\mathrm{M} / 4 \mathrm{~m}$ & stool & 01.02 .2012 & 3 \\
\hline & S146 & & 77 & F/88y & urine & 22.11 .2010 & 6 \\
\hline & S147 & & NA & $\mathrm{NA}$ & RIVM & $\mathrm{NA}$ & NA \\
\hline & $\mathrm{S} 148$ & & 78 & M/25y & stool & 20.06 .2010 & 3 \\
\hline & S149 & & NA & NA & RIVM & NA & NA \\
\hline
\end{tabular}


Table 1 continued

\begin{tabular}{|c|c|c|c|c|c|c|c|}
\hline Serovar & Isolate no. & Antigenic formulae & Patient ID & Sex/age & Origin & Collection date [d.m.y] & Place of isolation $\mathrm{ID}^{\mathrm{a}}$ \\
\hline & S150 & & NA & NA & RIVM & NA & NA \\
\hline & S151 & & 79 & $\mathrm{~F} / ?$ & stool & 30.04 .2008 & 1 \\
\hline & $\mathrm{S} 152$ & & 80 & $\mathrm{~K} / 51 \mathrm{y}$ & stool & 06.06 .2007 & 6 \\
\hline & S153 & & 81 & M/19y & stool & 25.05 .2007 & 6 \\
\hline & S154 & & 82 & $\mathrm{M} / 3 \mathrm{~m}$ & stool & 18.05 .2007 & 6 \\
\hline & S155 & & 83 & $\mathrm{~F} / 8 \mathrm{~m}$ & stool & 15.09.2006 & 7 \\
\hline & S156 & & $?$ & $?$ & stool & 13.05 .2006 & 8 \\
\hline & S157 & & $?$ & $?$ & $?$ & (11.01.2006) & 1 \\
\hline & S158 & & $?$ & $?$ & urine & $(05.01 .2006)$ & 6 \\
\hline & S159 & & NA & NA & food & $(30.11 .2005)$ & NA \\
\hline & S160 & & $?$ & $?$ & stool & $(25.08 .2005)$ & 3 \\
\hline & S161 & & $?$ & $?$ & stool & 05.03 .2005 & 8 \\
\hline & S162 & & $?$ & $?$ & stool & $(07.05 .2004)$ & 3 \\
\hline & S163 & & $?$ & $?$ & stool & (18.02.2004) & 3 \\
\hline & S164 & & $?$ & $?$ & $?$ & $(05.01 .2004)$ & 3 \\
\hline \multirow[t]{22}{*}{ Hadar } & S002 & 6,8:z10:e,n,x & 60 & F/61y & stool & 20.02.2009 & 1 \\
\hline & S012 & & 61 & $\mathrm{~F} / 17 \mathrm{~m}$ & stool & 25.03 .2009 & 1 \\
\hline & S104 & & $?$ & $?$ & stool & $(04.04 .2011)$ & 2 \\
\hline & S185 & & NA & NA & RIVM & NA & NA \\
\hline & S186 & & NA & NA & RIVM & NA & NA \\
\hline & S187 & & NA & NA & RIVM & NA & NA \\
\hline & S188 & & $?$ & $?$ & stool & 22.10 .2007 & 7 \\
\hline & S189 & & 89 & $\mathrm{M} / ?$ & stool & 28.07 .2007 & 7 \\
\hline & S190 & & 90 & $\mathrm{M} / 22 \mathrm{y}$ & stool & 02.05 .2007 & 6 \\
\hline & S191 & & 91 & M/19y & stool & 24.05 .2007 & 6 \\
\hline & S192 & & 92 & $\mathrm{M} / 10 \mathrm{y}$ & stool & 25.05 .2007 & 6 \\
\hline & S193 & & 93 & $\mathrm{~F} / 18 \mathrm{y}$ & stool & 05.06 .2007 & 6 \\
\hline & S194 & & $?$ & $?$ & $?$ & 16.01 .2007 & 6 \\
\hline & S195 & & $?$ & $?$ & $?$ & 16.01 .2007 & 6 \\
\hline & S196 & & $?$ & $?$ & $?$ & 16.01 .2007 & 6 \\
\hline & S197 & & NA & NA & food & (16.11.2006) & NA \\
\hline & S198 & & NA & NA & food & $(20.09 .2006)$ & NA \\
\hline & S199 & & NA & NA & food & (05.01.2006) & NA \\
\hline & S200 & & $?$ & $?$ & blood & 15.11.2005 & 3 \\
\hline & S201 & & $?$ & $?$ & stool & 19.09 .2005 & 3 \\
\hline & S202 & & NA & NA & food & (17.11.2005) & NA \\
\hline & S203 & & NA & NA & food & $(02.11 .2005)$ & NA \\
\hline \multirow[t]{11}{*}{ Virchow } & S027 & 6,7,14:r:1,2 & 14 & $\mathrm{~F} / 16 \mathrm{~m}$ & stool & 27.05.2009 & 1 \\
\hline & S034 & & 15 & $\mathrm{~F} / 9 \mathrm{~m}$ & stool & 24.06 .2009 & 1 \\
\hline & S035 & & 15 & $\mathrm{~F} / 9 \mathrm{~m}$ & stool & 27.08.2009 & 1 \\
\hline & S036 & & 16 & $\mathrm{M} / 7 \mathrm{~m}$ & stool & 27.08.2009 & 1 \\
\hline & S107 & & 17 & $?$ & stool & $(04.04 .2011)$ & 2 \\
\hline & $\mathrm{S} 114$ & & 18 & $\mathrm{~F} / 4 \mathrm{y}$ & stool & 13.09.2010 & 2 \\
\hline & $\mathrm{S} 115$ & & 18 & $\mathrm{~F} / 4 \mathrm{y}$ & stool & 09.09 .2010 & 2 \\
\hline & $\mathrm{S} 120$ & & 19 & $?$ & stool & $(04.04 .2011)$ & 2 \\
\hline & S165 & & 84 & $\mathrm{M} / 18 \mathrm{y}$ & stool & 20.10 .2010 & 6 \\
\hline & S166 & & NA & NA & RIVM & NA & NA \\
\hline & S167 & & $?$ & $?$ & $?$ & $(01.03 .2010)$ & 1 \\
\hline
\end{tabular}


Table 1 continued

\begin{tabular}{|c|c|c|c|c|c|c|c|}
\hline Serovar & Isolate no. & Antigenic formulae & Patient ID & Sex/age & Origin & Collection date [d.m.y] & Place of isolation ID $^{\mathrm{a}}$ \\
\hline & S168 & & NA & NA & food & $(07.01 .2010)$ & NA \\
\hline & S169 & & NA & NA & RIVM & NA & NA \\
\hline & S170 & & 85 & $\mathrm{M} / ?$ & blood & 02.11 .2009 & 6 \\
\hline & S171 & & $?$ & $?$ & stool & 04.09.2009 & 8 \\
\hline & S172 & & $?$ & $?$ & stool & 28.08.2009 & 8 \\
\hline & S173 & & $?$ & $?$ & stool & 21.08.2009 & 8 \\
\hline & S174 & & 86 & $\mathrm{~F} / ?$ & stool & 03.04.2009 & 7 \\
\hline & S175 & & 86 & $\mathrm{~F} / ?$ & stool & 03.04.2009 & 7 \\
\hline & S176 & & 86 & $\mathrm{~F} / ?$ & stool & 03.04.2009 & 7 \\
\hline & S177 & & NA & NA & RIVM & NA & NA \\
\hline & S178 & & $?$ & $?$ & stool & 12.11.2007 & 8 \\
\hline & S179 & & $?$ & $?$ & stool & 07.09 .2007 & 8 \\
\hline & $\mathrm{S} 180$ & & $?$ & $?$ & stool & 24.08.2007 & 8 \\
\hline & S181 & & $?$ & $?$ & stool & 25.07.2007 & 7 \\
\hline & S182 & & 87 & $\mathrm{M} / 27 \mathrm{y}$ & stool & 01.06 .2007 & 4 \\
\hline & S183 & & 88 & $\mathrm{M} / ?$ & tissue & $(04.10 .2006)$ & 3 \\
\hline & S184 & & $?$ & $?$ & stool & (07.09.2006) & 9 \\
\hline \multirow[t]{31}{*}{ Enteritidis } & S001 & 1,9,12:g,m:- & 20 & $\mathrm{M} / 30 \mathrm{~m}$ & stool & 29.01.2009 & 1 \\
\hline & S007 & & 21 & $\mathrm{M} / 16 \mathrm{~m}$ & stool & 18.03.2009 & 1 \\
\hline & S008 & & 64 & $\mathrm{~F} / 36 \mathrm{~m}$ & stool & 18.03.2009 & 1 \\
\hline & S009 & & 22 & M/9y & stool & 18.03.2009 & 1 \\
\hline & S014 & & 25 & $\mathrm{M} / 28 \mathrm{~m}$ & stool & 31.03.2009 & 1 \\
\hline & S015 & & 26 & $\mathrm{M} / 5 \mathrm{y}$ & stool & 16.04.2009 & 1 \\
\hline & S016 & & 27 & $\mathrm{~F} / 5 \mathrm{y}$ & stool & 31.03.2009 & 1 \\
\hline & S017 & & 25 & $\mathrm{M} / 29 \mathrm{~m}$ & stool & 16.04.2009 & 1 \\
\hline & S021 & & 25 & $\mathrm{M} / 29 \mathrm{~m}$ & stool & 16.04.2009 & 1 \\
\hline & S022 & & 28 & $\mathrm{~F} / 11 \mathrm{~m}$ & stool & 23.04.2009 & 1 \\
\hline & S023 & & 29 & $\mathrm{~F} / 16 \mathrm{~m}$ & stool & 29.04.2009 & 1 \\
\hline & S024 & & 30 & $\mathrm{~F} / 10 \mathrm{~m}$ & stool & 14.05.2009 & 1 \\
\hline & S028 & & 31 & M/76y & stool & 14.05.2009 & 1 \\
\hline & S029 & & 32 & $\mathrm{~F} / 36 \mathrm{~m}$ & stool & 14.05.2009 & 1 \\
\hline & S030 & & 33 & $\mathrm{M} / 30 \mathrm{~m}$ & stool & 10.06.2009 & 1 \\
\hline & S031 & & 34 & $\mathrm{~F} / 13 \mathrm{~m}$ & stool & 10.06.2009 & 1 \\
\hline & S032 & & 35 & $\mathrm{M} / 74 \mathrm{y}$ & stool & 10.06.2009 & 1 \\
\hline & S033 & & 36 & $\mathrm{~F} / 4 \mathrm{y}$ & stool & 10.06.2009 & 1 \\
\hline & S037 & & 37 & $\mathrm{~F} / 5 \mathrm{y}$ & stool & 24.06.2009 & 1 \\
\hline & S039 & & 38 & $\mathrm{~F} / 15 \mathrm{~m}$ & stool & 27.08.2009 & 1 \\
\hline & S040 & & 39 & $\mathrm{M} / 27 \mathrm{~m}$ & stool & 27.08.2009 & 1 \\
\hline & S041 & & 40 & $\mathrm{M} / 4 \mathrm{y}$ & stool & 27.08.2009 & 1 \\
\hline & S043 & & 41 & $\mathrm{~F} / 13 \mathrm{~m}$ & stool & 27.08.2009 & 1 \\
\hline & S044 & & 42 & $\mathrm{M} / 27 \mathrm{~m}$ & stool & 27.08 .2009 & 1 \\
\hline & S045 & & 43 & $\mathrm{~F} / 37 \mathrm{~m}$ & stool & 27.08.2009 & 1 \\
\hline & S046 & & 44 & $\mathrm{~F} / 24 \mathrm{~m}$ & stool & 27.08.2009 & 1 \\
\hline & S047 & & 45 & $\mathrm{~F} / 25 \mathrm{~m}$ & stool & 27.08 .2009 & 1 \\
\hline & S049 & & 46 & $\mathrm{M} / 4 \mathrm{y}$ & stool & 27.08.2009 & 1 \\
\hline & S052 & & 47 & $\mathrm{M} / 21 \mathrm{~m}$ & stool & 08.09.2009 & 1 \\
\hline & S053 & & 48 & $\mathrm{~F} / 22 \mathrm{y}$ & stool & 08.09.2009 & 1 \\
\hline & S055 & & 49 & $\mathrm{~F} / 73 \mathrm{y}$ & stool & 08.09.2009 & 1 \\
\hline
\end{tabular}


Table 1 continued

\begin{tabular}{|c|c|c|c|c|c|c|c|}
\hline Serovar & Isolate no. & Antigenic formulae & Patient ID & Sex/age & Origin & Collection date [d.m.y] & Place of isolation $\mathrm{ID}^{\mathrm{a}}$ \\
\hline & S056 & & 50 & $\mathrm{M} / 24 \mathrm{~m}$ & stool & 08.09.2009 & 1 \\
\hline & S063 & & 51 & $\mathrm{M} / 22 \mathrm{~m}$ & stool & 29.09.2009 & 1 \\
\hline & S065 & & 52 & $\mathrm{M} / 26 \mathrm{~m}$ & stool & 29.09 .2009 & 1 \\
\hline & S066 & & 53 & $\mathrm{~F} / 17 \mathrm{~m}$ & stool & 29.09.2009 & 1 \\
\hline & S067 & & 54 & $\mathrm{~F} / 87 \mathrm{y}$ & stool & 29.09 .2009 & 1 \\
\hline & S068 & & 55 & $\mathrm{~F} / 5 \mathrm{y}$ & stool & 29.09 .2009 & 1 \\
\hline & S069 & & 56 & M/9y & stool & 13.10 .2009 & 1 \\
\hline & S070 & & 57 & $\mathrm{~F} / 19 \mathrm{~m}$ & stool & 13.10 .2009 & 1 \\
\hline & S071 & & 65 & $\mathrm{~F} / 5 \mathrm{y}$ & stool & 13.10 .2009 & 1 \\
\hline & S073 & & 58 & $\mathrm{~F} / 11 \mathrm{~m}$ & stool & 29.10 .2009 & 1 \\
\hline \multirow[t]{8}{*}{ Anatum } & S026 & $3,\{10\}\{15\}\{15,34\}: \mathrm{e}, \mathrm{h}: 1,6$ & 59 & $\mathrm{M} / 4 \mathrm{y}$ & stool & 27.05.2009 & 1 \\
\hline & S204 & & NA & NA & RIVM & NA & NA \\
\hline & S205 & & 96 & $\mathrm{~F} / 71 \mathrm{y}$ & stool & 14.05.2007 & 6 \\
\hline & S206 & & $?$ & $?$ & stool & $(09.03 .2005)$ & 3 \\
\hline & S207 & & $?$ & $?$ & stool & $(07.06 .2003)$ & 3 \\
\hline & S208 & & $?$ & $?$ & stool & $(07.06 .2003)$ & 3 \\
\hline & S209 & & $?$ & $?$ & stool & 21.05 .2003 & 3 \\
\hline & S210 & & $?$ & $?$ & stool & 21.05 .2003 & 3 \\
\hline \multirow[t]{8}{*}{ Newport } & S083 & 6,8,20:e,h:1,2 & 62 & $\mathrm{M} / 6 \mathrm{~m}$ & stool & 03.12.2009 & 1 \\
\hline & S211 & & NA & NA & RIVM & NA & NA \\
\hline & S212 & & 94 & $\mathrm{~F} / ?$ & stool & 17.07.2009 & 6 \\
\hline & S213 & & NA & NA & food & (20.08.2008) & NA \\
\hline & S214 & & 95 & $\mathrm{~F} / 38 \mathrm{y}$ & stool & 07.11 .2007 & 6 \\
\hline & S215 & & $?$ & $?$ & $?$ & $(25.08 .2005)$ & 3 \\
\hline & S216 & & $?$ & $?$ & stool & $(06.10 .2003)$ & 8 \\
\hline & $\mathrm{S} 217$ & & $?$ & $?$ & stool & 27.02 .2003 & 8 \\
\hline
\end{tabular}

a The same number refers to the same region of Poland (voivodeship) but different hospital/diagnostic laboratory

${ }^{\mathrm{b}}$ In brackets there is date of isolate receiving

? unknown, $N A$-not applicable, $F$ Female, $M$ Male, $y$ years, $m$ months

RIVM - strains obtained from The Netherlands National Institute for Public Health and the Environment

presence of trinucleotide repeat sequences (TRSs) dispersed throughout the bacterial genome. This method uses primers that are complementary to commonly occurring trinucleotide repeat DNA sequences. Previously, we evaluated the $(\mathrm{CGG})_{4}$-based PCR for the discrimination of uropathogenic Escherichia coli $[8]$, a (CAC) $)_{4}$-based PCR for the discrimination of Mycobacterium gordonae [9] and a (CCG) $4^{-}$ based PCR for the discrimination of Mycobacterium kansasii [10] and Mycobacterium avium [11]. In the present work, we examined a collection of 170 clinical S. enterica strains (Table 1). This collection consisted of the $S$. Enteritidis and $S$. Typhimurium serovars, which are the top two serovars isolated from humans in Poland and also serovars that are still of great clinical importance ( $S$. Infantis, $S$. Virchow, $S$. Hadar, $S$. Anatum and $S$. Newport) [1]. The objective of the project was to implement a simple test that (i) is able to distinguish the $S$. Enteritidis and $S$. Typhimurium serovars and (ii) has the potential to discriminate among other serovars, such as $S$. Infantis, $S$. Virchow, $S$. Hadar, $S$. Anatum and $S$. Newport. This method could be used as a preliminary approach for Salmonella discrimination in order to reduce the cost of serotyping.

\section{Materials and methods}

\section{Bacterial strains}

All of the strains used in this study were collected from the SYNEVO Medical Laboratory (Lodz, Poland), National Institute of Public Health (Warsaw, Poland) and Institute of Genetics and Microbiology (University of Wroclaw, Poland) from June 2003 to April 2012 (Table 1). The RIVM strains were obtained from The Netherlands National Institute for Public Health and the Environment (Table 1). A total of 170 strains were isolated from humans 
and food samples with Salmonella infections in laboratories mentioned above and they were biochemically identified and serotyped by a slide agglutination test with specific $\mathrm{O}$ and $\mathrm{H}$ antisera, and classified according to the White-Kauffmann-Le Minor scheme [6]. We obtained clean, serologically characterized isolates that were used for further studies. The whole collection consisted of: 41 strains of $S$. Enteritidis, 38 strains of $S$. Typhimurium, 25 strains of $S$. Infantis, 28 strains of $S$. Virchow, 22 strains of $S$. Hadar, 8 strains of both $S$. Anatum and $S$. Newport.

Bacterial growth and genomic DNA isolation

For further studies, after isolation of a single colony from SS Agar (Salmonella Shigella Agar), all of the isolates were grown in liquid LB broth at $37{ }^{\circ} \mathrm{C}$ overnight with an agitation speed of 120 RPM. The genomic DNA was isolated using a GenElute Bacterial Genomic DNA Kit (Sigma-Aldrich, St. Louis, MO). The purity and quantity of the DNA were determined spectrophotometrically at $260 \mathrm{~nm}$ (BioPhotometer, Eppendorf, Germany).

TRS-PCR and fingerprint analysis

The primers were designed to conform to the $5^{\prime}-\mathrm{N}_{6}(\mathrm{TRS})_{4}$ $3^{\prime}$ scheme in which $\mathrm{N}$ represents $\mathrm{G}, \mathrm{A}, \mathrm{T}$ or $\mathrm{C}$ in a random manner. The TRS-PCR, electrophoresis, reproducibility assessments and bioinformatic analyses were performed as reported in previously published protocols [8-10], with the exception of the DNA template concentration. The TRSPCRs were performed in a final volume of $50 \mu \mathrm{l}$ using $10 \mathrm{ng}$ of the isolated DNA, $1 \mathrm{U}$ Taq polymerase
(Invitrogen by Life Technologies, CA, USA), $1 \times$ polymerase buffer, $1.5 \mathrm{mM}$ of $\mathrm{MgCl}_{2}, 50 \mathrm{pmol}$ of TRS-primer (each containing a single TRS motif), $0.2 \mathrm{mM}$ of each deoxynucleoside triphosphate and $6 \%$ DMSO. The PCR amplifications were accomplished using a T-3000 termocycler (Biometra, Goettingen, Germany) with an initial denaturation step $\left(95{ }^{\circ} \mathrm{C}, 3 \mathrm{~min}\right)$ followed by 35 cycles of denaturation $\left(95^{\circ} \mathrm{C}, 1 \mathrm{~min}\right)$, annealing (variable temperatures - Table $2,1 \mathrm{~min})$, extension $\left(72{ }^{\circ} \mathrm{C}, 2 \mathrm{~min}\right)$ and final extension step $\left(72{ }^{\circ} \mathrm{C}, 8 \mathrm{~min}\right)$. The PCR products, $10 \mu \mathrm{l}$ of $50 \mu \mathrm{l}$, were resolved by horizontal electrophoresis on $1.6 \%$ agarose gel in a $1 \times$ TAE buffer. Electrophoresis was performed at room temperature and $70 \mathrm{~V}(2.4 \mathrm{~V} / \mathrm{cm})$ until the dye (Bromophenol blue) migrated $6 \mathrm{~cm}$ from the wells $(\sim 2 \mathrm{~h})$. Afterwards, gels were stained in an $\mathrm{EtBr}$ solution $(0.5 \mu \mathrm{g} / \mathrm{ml})$ for $10 \mathrm{~min}$ and destained in water for another $10 \mathrm{~min}$. The images of the gels were captured under UV light using a FluorChem 8800 system with Alpha EaseFC v. 3.1.2 software (AlphaInnotech, CA, USA). The cluster analyses of the TRS-PCR and ERIC-PCR genomic profiles were carried out with BioNumerics software (Applied Maths, Belgium). The sizes of PCR products in each lane of the agarose gel were normalized with regard to the 100 bp DNA size marker (Fermentas, Thermo Scientific Waltham, MA, USA). The fingerprint similarity comparisons were calculated using a Pearson correlation (optimization $1 \%$, position tolerance $1 \%$ ) and grouping was done according to the UPGMA algorithm. The ERICPCR was performed as described elsewhere [8, 9, 12] except for the DNA concentration $(\sim 10 \mathrm{ng} / \mu \mathrm{l})$. The reproducibility of TRS-PCR and ERIC-PCR was obtained by comparing the three separate fingerprints (from three

Table 2 Parameters of the TRS-PCR

\begin{tabular}{|c|c|c|c|c|}
\hline $\begin{array}{l}\text { TRS motif (direct/ } \\
\text { complementary) }\end{array}$ & $\begin{array}{l}\text { Theoretical number of } \\
\text { motifs (TRS) } n \geq 3^{\text {a }}\end{array}$ & $\begin{array}{l}\text { Annealing temperatures of the } \\
\text { TRS primers }\left({ }^{\circ} \mathrm{C}\right)\end{array}$ & $\begin{array}{l}\text { Practical utility of the } \\
\text { TRS primers }\end{array}$ & $\begin{array}{l}\text { Reproducibility of the } \\
\text { band patterns }(\%)^{\mathrm{c}}\end{array}$ \\
\hline $\mathrm{CGG} / \mathrm{CCG}$ & 1,035 & 72 & $"+"$ & $94.8 / 94.5$ \\
\hline CTG/CAG & 478 & 61 & & 94.7/ND \\
\hline GTG/CAC & 294 & $55 / 61$ & & $95.7 / 96.6$ \\
\hline ATG/CAT & 267 & 44 & $“ \pm ”$ & ND \\
\hline AAG/CTT & 172 & 44 & & \\
\hline GTC/GAC & 140 & 61 & & \\
\hline TTG/CAA & 115 & 45 & & \\
\hline TAT/ATA & 203 & $<44$ & "-" & ND \\
\hline TCC/GGA & 42 & 61 & & \\
\hline TAG/CTA & 17 & 44 & & \\
\hline
\end{tabular}

${ }^{\text {a }}$ Based on in silico analysis of the genome of Salmonella Enteritidis str. P125109

b Based on PCR reactions, where "+" indicates fingerprints with good quality, “ \pm " indicates fingerprints with poor quality, and “-” indicates no product

c The reproducibility of the TRS-PCR was obtained by comparing (Pearson correlation, UPGMA algorithm) the three separate fingerprints (from three different PCR runs) of one selected strain from investigated serovars; the numbers show the mean same strain similarity values

ND Not Determined 
different PCR runs) of one selected strain from each of the investigated serovars.

\section{Results}

In silico analysis

In silico analysis of the entire genome sequence data of $S$. Enteritidis (str. P125109, GenBank acc. no. AM933172) was conducted (Vector NTI 9.0.0.) to estimate the number of trinucleotide repeat tracts. This approach enabled us to predict the utility of the TRS-containing primers. There are 64 possible combinations of trinucleotide repeats. However, after eliminating four mononucleotide repetitions as well as taking into account the fact that each of the motifs can be written as three equivalent frames (i.e., $\mathrm{CTG}=\mathrm{TGC}=\mathrm{GCT}$ ), it appears that only 20 motifs are sufficient for planning a complete set of primers for the TRS-PCR test. The theoretical calculations yielded a number of TRS motifs scattered on both strands and not the number of possible amplicons that may be generated by PCR (Table 2). Therefore, we decided to implement the TRS-based PCR separately for each of the 20 primers.

\section{Reference method}

To select a rep-PCR-based test as the reference method, we performed three manual rep-PCRs, as follows: REP-PCR (primers REP-2I and REP-1R), BOX-PCR (primer BOXA1R) and ERIC-PCR (primers ERIC-1R and ERIC-2). These typing methods were formerly used for gram-negative enterobacterial strain differentiation [12-16] and, as well as TRS-PCR, rely on an amplification of genomic DNA fragments using sets of primers complementary to the short repetitive sequences. Among REP-, BOX- and ERICPCR methods, only ERIC-PCR produced fingerprints with good quality and resolution (data not shown); therefore, this method was chosen as the rep-PCR reference method for typing the 170 isolates of $S$. enterica.

TRS-based PCR: preliminary analysis

Preliminary tests were conducted on a collection of 32 strains from the seven investigated serovars (10 strains of $S$. Enteritidis, 10 strains of $S$. Typhimurium and three strains from each of the remaining serovars: $S$. Virchow, $S$. Infantis, $S$. Newport, $S$. Anatum). In these studies, 14 of the 20 primers with TRS motifs produced fingerprints. Four of the primers, containing the motifs TCC, AGG, TAG and TAC, produced no products, as was expected from our in silico analysis (low theoretical number of TRS motifs, Table 2). In the case of the primers harboring the TAT and
ATA motifs, the annealing temperature (below $44^{\circ} \mathrm{C}$ ) probably did not allow the amplification of any product. Eight primers, containing the motifs GTC, GAC, TTG, AAC, AAG, TTC, ATG and ATC, produced poor-quality profiles (data not shown). Six primers, containing the motifs CAC, CGG, CCG, CTG, CAG and GTG, produced complex fingerprints with good resolution and discrimination potential. However, only five of these primers (all except $\mathrm{CAG}$ ) fulfilled the first of our assumptions, that is, distinguishing the $S$. Enteritidis and $S$. Typhimurium serovars.

TRS-based PCR: inter-serovar discrimination

The TRS-based band pattern analyses employing $\mathrm{N}_{6}(\mathrm{CAC})_{4}, \mathrm{~N}_{6}(\mathrm{CGG})_{4}, \mathrm{~N}_{6}(\mathrm{CCG})_{4}$ and $\mathrm{N}_{6}(\mathrm{CTG})_{4}$ primers for the $S$. Enteritidis and $S$. Typhimurium strains are shown in Fig. 1a, b, c and d, respectively. Isolates of the same serovar clustered together and were represented by similar fingerprints. Moreover, PCR genotyping with the $\mathrm{N}_{6}(\mathrm{GTG})_{4}$ primer generated highly uniform fingerprints for all seven serotypes, therefore, this primer was used for analysis of the whole 170 Salmonella enterica subsp. enterica strain collection.

With use of (GTG) $)_{4}$-based PCR it was possible to classify Salmonella isolates into genetically related clusters that were, for the most part, homogeneous for serotype (Fig. 2). However, there were some inaccuracies with strain S211, described as $S$. Newport (marked with a double dot, Fig. 2). Further investigations showed that this strain is in fact $S$. Bardo (I 8:e,h:1,2), which is very similar to $S$. Newport (I 6,8:e.h:1,2). Classical serotyping by slide agglutination test with specific $\mathrm{O}$ and $\mathrm{H}$ antisera may be susceptible to colonial form variations that may occur with the expression of the O:6 antigen [17]. Hendriksen et al. [18] conceded, for needs of WHO Global Salm-Surv EQAS, that both identifications could be treated as correct. Although, phenotypically such serotypes could converge on each other, our results suggest that genotypically they remain different. Interestingly, an additional serotype analysis performed with a Premi ${ }^{\circledR}$ Test Salmonella microarray (check-points, Netherlands, data not shown) has confirmed the wrong classification of this strain as $S$. Newport. Notably, the $(\mathrm{GTG})_{4}$-based PCR analysis was also capable of revealing errors in laboratory documentation. Strains S027, S114 and S115 were originally classified as $S$. Infantis (strains marked with a single dot, Fig. 2). Their (GTG) ${ }_{4}$-based fingerprints were visibly different from the profiles of the serotypes to which they were assigned. In our analyses, these strains grouped with $S$. Virchow, which was confirmed by serotyping re-analysis.

$(\text { GTG })_{4}$-based PCR clustering analysis showed that similarities of strains within serovars $S$. Enteritidis, $S$. 
Typhimurium, $S$. Virchow, $S$. Infantis, $S$. Hadar, $S$. Newport and $S$. Anatum were 88, 91.1, 71.6, 90.7, 90.1, 94.2 and $89.2 \%$, respectively (Table 3 , bold values). From these values, serovar $S$. Virchow seemed to be more variable. However, Fig. 2 shows that although two strains-S169 and S183-differed slightly from fingerprints of the other strains in the respective group, they still remained within the group. Cluster-to-cluster analysis demonstrated that similarities among serovar clusters were lower than the pattern similarity for all of the strains in a given cluster (Table 3).

\section{Reproducibility of TRS-PCR and ERIC-PCR}

The reproducibility of TRS-PCR was calculated for the three chosen strains representing each serovar according to previously published protocols $[8,9,11]$. In the current reproducibility analysis, the mean same-strain similarity values were also high (Table 2). The ERIC-PCR exhibited significantly lower reproducibility $(77 \%)$ and was not able to cluster all of the strains properly (data not shown).

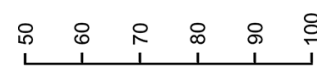

\section{A}

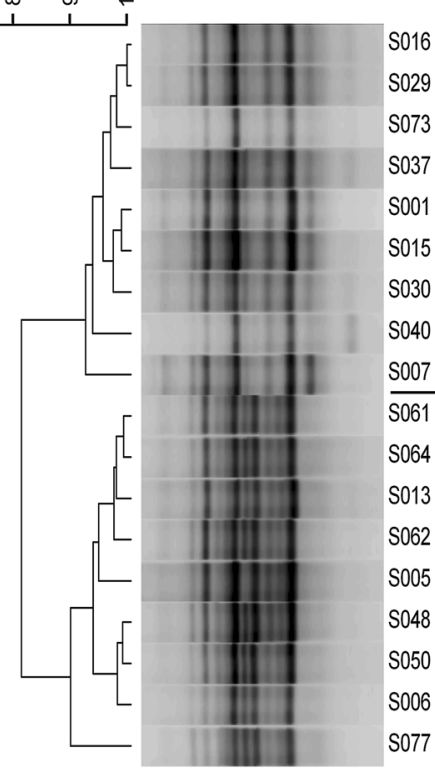

Enteritidis

요 8 요윰

B
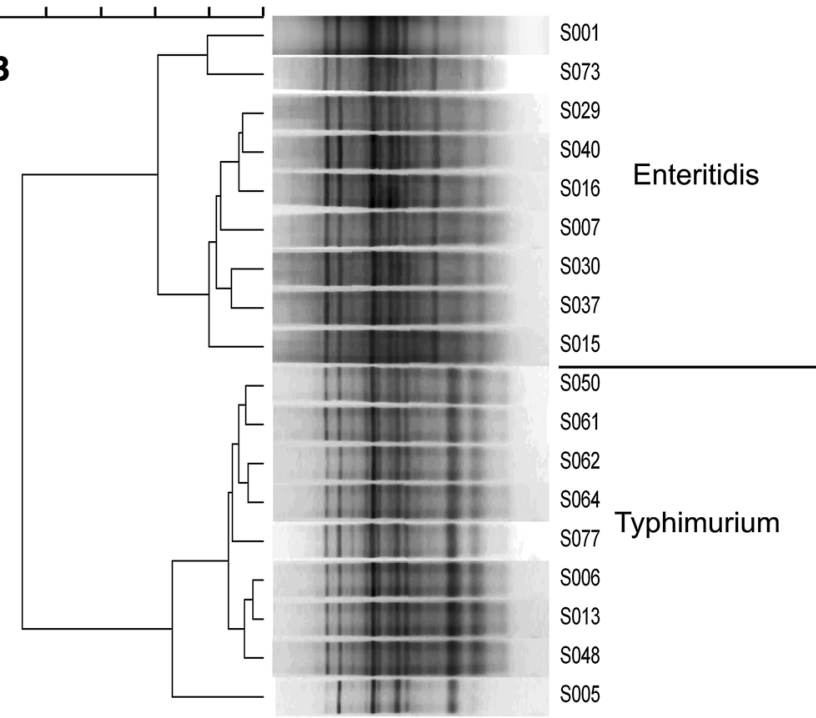

요요

D

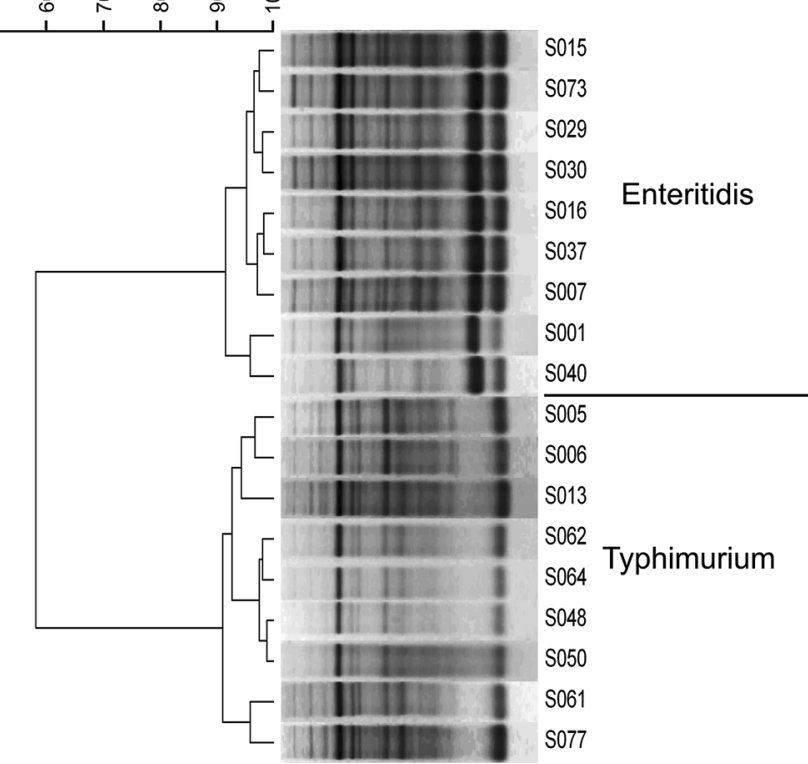

between fingerprints were calculated using the Pearson correlation (optimization $1.00 \%$, position tolerance $1.00 \%$ ) and the fingerprints were grouped by use of the UPGMA algorithm 


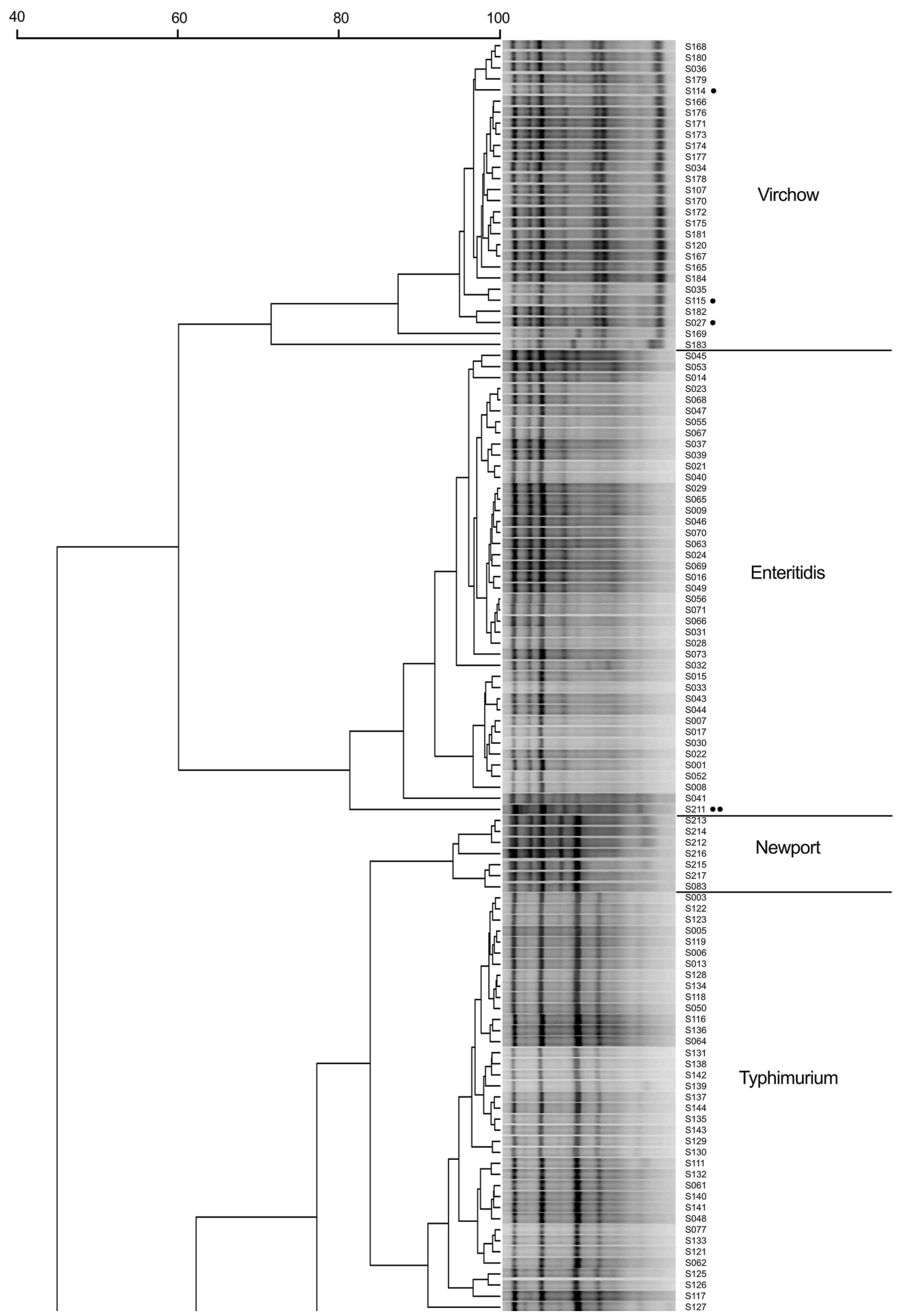

Fig. $2 \mathrm{~N}_{6}(\mathrm{GTG})_{4}$-based fingerprint similarity comparison of 170 Salmonella enterica subsp. enterica strains. The similarities between fingerprints were calculated using the Pearson correlation (optimization $1.00 \%$, position tolerance $1.00 \%$ ) and the fingerprints were grouped by use of the UPGMA algorithm. • - strains originally classified as $S$. Infantis; ••-strain S211 re-identified as $S$. Bardo 


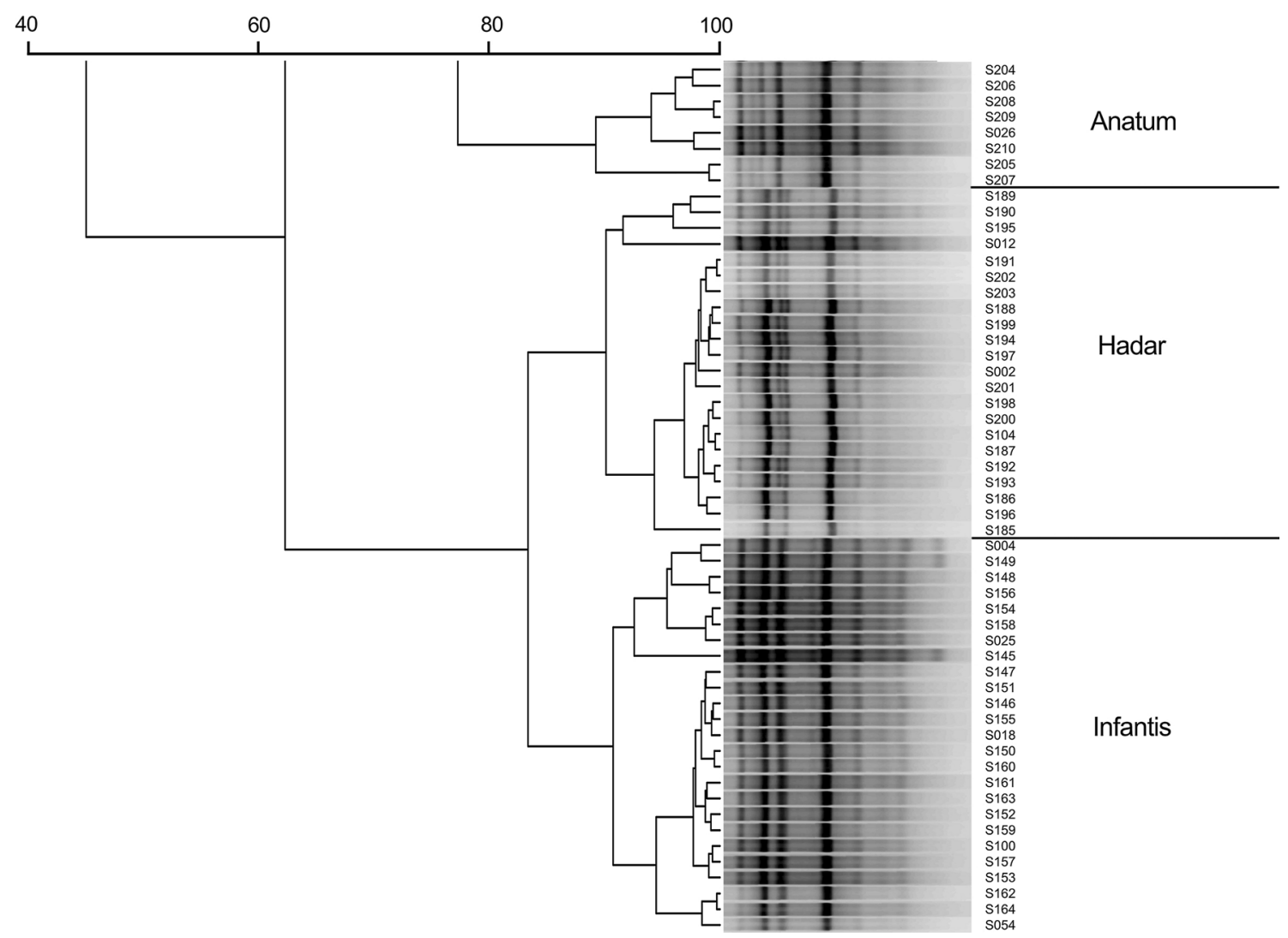

Fig. 2 continued

Table 3 Inter- and intra-cluster similarities [\%] based on GTGPCR band patterns of 7 Salmonella serovars

${ }^{\text {a }}$ Without strain S211; values in bold indicate intra-serovar similarities

\begin{tabular}{llllllll}
\hline & Virchow & Enteritidis & Newport $^{\mathrm{a}}$ & Typhimurium & Anatum & Hadar & Infantis \\
\hline Virchow & $\mathbf{7 1 . 6}$ & 60.4 & 35.9 & 42.4 & 31.5 & 15.2 & 29.8 \\
Enteritidis $^{\text {a }}$ & 60.4 & $\mathbf{8 8 . 0}$ & 67.8 & 61.0 & 50.3 & 35.6 & 55.8 \\
Newport $^{\mathrm{a}}$ & 35.9 & 67.8 & $\mathbf{9 4 . 2}$ & 83.9 & 76.5 & 65.7 & 68.9 \\
Typhimurium $^{2}$ & 42.4 & 61.0 & 83.9 & $\mathbf{9 1 . 1}$ & 77.3 & 57.5 & 60.3 \\
Anatum & 31.5 & 50.3 & 76.5 & 77.3 & $\mathbf{8 9 . 2}$ & 63.5 & 81.5 \\
Hadar & 15.2 & 35.6 & 65.7 & 57.5 & 63.5 & $\mathbf{9 0 . 1}$ & 83.4 \\
Infantis & 29.8 & 55.8 & 68.9 & 60.3 & 81.5 & 83.4 & $\mathbf{9 0 . 7}$ \\
\hline
\end{tabular}

Taking all the above into consideration, a (GTG) $)_{4}$-based PCR was useful for effective, reproducible, inter-serovar discrimination of this Salmonella collection.

\section{Discussion}

The use of rep-PCR-based genotyping for Salmonella enterica using the $(\mathrm{GTG})_{5}$ primer has been published previously. Rasschaert et al. [16] concluded that the composite dataset for ERIC and the $(\mathrm{GTG})_{5}$ primers provided serotype discrimination and suggested this rep-PCR be used to limit the number of strains that had to be serotyped. However, the authors emphasized that the reproducibility of the tests was lower if the isolates were analyzed during different PCR runs, and that there were two strains of $S$. Enteritidis that fell out of the main cluster of this serovar. Because we aimed to identify an easy, rapid and reproducible method for the differentiation of Salmonella isolates, the use of a single primer was more desirable than the composite analysis. We designed a set of TRS primers according to a $5^{\prime}-\mathrm{N}_{6}(\mathrm{TRS})_{4}-3^{\prime}$ scheme. In our case, the additional $\mathrm{N}_{6}$-tail at the $5^{\prime}$ end allows better anchoring to the various TRS-loci of the genomic template. Therefore, in our opinion, the use of a single primer- $\mathrm{N}_{6}(\mathrm{GTG})_{4}$-was sufficient to obtain reproducible and satisfactory results.

Formerly, the (GTG) $)_{5}$-PCR technique was found to be a rapid and simple tool to reproducibly discriminate among a wide range of Lactobacillus species [19]. Also, this method was successfully applied in the typing of fecal and 
environmental $E$. coli isolates in comparison with other rep-PCR methods, including ERIC-PCR, REP-PCR and BOX-PCR [20]. In other studies, methods using the $(\mathrm{GTG})_{5}$ primer were evaluated for the identification of Streptococcus mutans, Bacillus spp. and Klebsiella isolates [21-23]. However, these studies lacked reproducibility analyses, and there were some inaccuracies in the grouping of the bacterial isolates.

In our collection, there were no $S$. Dublin strains, which are closely related to $S$. Enteritidis and 4,5,12:i:-strains representing a monophasic variant of $S$. Typhimurium. Thus, we could not verify if our test would be able to distinguish these serovars properly. Such analyses are in progress but still require some further investigations. The range of serovars examined in our studies was limited; therefore, it would be desirable to investigate a more diverse population of Salmonella enterica strains in the future. Herein, we report that the $\mathrm{N}_{6}(\mathrm{GTG})_{4}$-PCR methodology can be used for rapid and easy single-tube DNA-based assays for the discrimination of seven $S$. enterica subsp. enterica serovars. The determination of TRS fingerprints for unknown Salmonella strains could serve as a useful predictor for their serovar affinity. Although conventional serotyping should still be performed, a rapid screen with TRS-based PCR may greatly reduce the number of antisera used for determination of Salmonella serovars and may help prioritize further investigation of Salmonella strains. It seems to be useful not only for examination of strains isolated from humans but also as a pilot survey of poultry, according to Commission Regulation No 1086/2011 [5].

Acknowledgments This work was co-financed by the European Regional Development Fund under Operational Programme Innovative Economy, Grant POIG.01.01.02-10-107/09.

Open Access This article is distributed under the terms of the Creative Commons Attribution License which permits any use, distribution, and reproduction in any medium, provided the original author(s) and the source are credited.

\section{References}

1. National Institute of Public Health (2010) Choroby Zakazne i Zatrucia w Polsce w 2009 Roku [Infectious Diseases and Poisonings in Poland in 2009]. Warsaw: National Institute of Public Health, Polish. Available from http://www.pzh.gov.pl/oldpage/ epimeld/2009/Ch_2009.pdf. Accessed 2010

2. National Institute of Public Health (2011) Choroby Zakazne i Zatrucia w Polsce w 2010 Roku [Infectious Diseases and Poisonings in Poland in 2010]. Warsaw: National Institute of Public Health, Polish. Available from http://www.pzh.gov.pl/oldpage/ epimeld/2010/Ch_2010.pdf. Accessed 2011

3. The European Union summary report on trends and sources of zoonoses, zoonotic agents and food-borne outbreaks in 2011. EFSA J 11:3129 (2013)
4. The community summary report on trends and sources of zoonoses, zoonotic agents and food-borne outbreaks in the European Union in 2008. EFSA J 8:1496 (2010)

5. Commission Regulation (EU) No 1086/2011 of 27 October 2011 Amending Annex II to Regulation (EC) No 2160/2003 of the European Parliament and of the Council and Annex I to Commission Regulation (EC) No 2073/2005 as regards Salmonella. Fresh Poult Meat Off J L 281(28 Oct):0007-0011 (2011)

6. Grimont PA, Weill FX (2007) Antigenic Formulae of the Salmonella Serovars 2007, 9th edn. Institut Pasteu, Paris

7. Liebana E, Guns D, Garcia-Migura L, Woodward MJ, CliftonHadley FA, Davies RH (2001) Molecular typing of Salmonella serotypes prevalent in animals in England: assessment of methodology. J Clin Microbiol 39:3609-3616

8. Adamus-Bialek W, Wojtasik A, Majchrzak M, Sosnowski M, Parniewski P (2009) (CGG)4-Based PCR as a novel tool for discrimination of uropathogenic Escherichia coli strains: comparison with enterobacterial repetitive intergenic consensus-PCR. J Clin Microbiol 47:3937-3944

9. Wojtasik A, Majchrzak M, Adamus-Bialek W, AugustynowiczKopec E, Zwolska Z, Dziadek J, Parniewski P (2011) Trinucleotide repeat sequence-based PCR as a potential approach for genotyping Mycobacterium gordonae strains. J Microbiol Methods 85:28-32

10. Kubiak AB, Wojtasik A, Augustynowicz-Kopec E, Zabost A, Zwolska Z, Parniewski P (2011) TRS-PCR-based genotyping of Mycobacterium kansasii. Progr Med XXIV:846-852

11. Wojtasik A, Kubiak AB, Kubiak AB, Krzyzanowska A, Majchrzak M, Augustynowicz-Kopec E, Parniewski P (2012) Comparison of the $(\mathrm{CCG})_{4}$-based PCR and MIRU-VNTR for molecular typing of Mycobacterium AVIUM strains. Mol Biol Rep 39(7):7681-7686

12. Versalovic J, Koeuth T, Lupski JR (1991) Distribution of repetitive DNA sequences in eubacteria and application to fingerprinting of bacterial genomes. Nucleic Acids Res 19:6823-6831

13. Burr MD, Josephson KL, Pepper IL (1998) An evaluation of ERIC PCR and AP PCR fingerprinting for discriminating Salmonella serotypes. Lett Appl Microbiol 27:24-30

14. Johnson JR, Clabots C, Azar M, Boxrud DJ, Besser JM, Thurn JR (2001) molecular analysis of a hospital cafeteria-associated salmonellosis outbreak using modified repetitive element PCR fingerprinting. J Clin Microbiol 39:3452-3460

15. Millemann Y, Lesage-Descauses MC, Lafont JP, Chaslus-Dancla E (1996) Comparison of random amplified polymorphic DNA analysis and enterobacterial repetitive intergenic consensus-PCR for epidemiological studies of Salmonella. FEMS Immunol Med Microbiol 14:129-134

16. Rasschaert G, Houf K, Imberechts H, Grijspeerdt K, De Zutter L, Heyndrickx M (2005) Comparison of five repetitive-sequencebased PCR typing methods for molecular discrimination of Salmonella enterica isolates. J Clin Microbiol 43:3615-3623

17. Franco A, Hendriksen RS, Lorenzetti S, Onorati R, Gentile G, Dell'Omo G, Aarestrup FM, Battisti A (2011) Characterization of Salmonella occurring at high prevalence in a population of the land Iguana Conolophus subcristatus in Galapagos Islands, Ecuador. PLoS One 6:e23147

18. Hendriksen RS, Mikoleit M, Carlson VP, Karlsmose S, Vieira AR, Jensen AB, Seyfarth AM, DeLong SM, Weill FX, Lo Fo Wong DM, Angulo FJ, Wegener HC, Aarestrup FM (2009) WHO global Salm-Surv external quality assurance system for serotyping of Salmonella isolates from 2000 to 2007. J Clin Microbiol 47:2729-2736

19. Gevers D, Huys G, Swings J (2001) Applicability of Rep-PCR fingerprinting for identification of Lactobacillus species. FEMS Microbiol Lett 205:31-36 
20. Mohapatra BR, Broersma K, Mazumder A (2007) Comparison of five Rep-PCR genomic fingerprinting methods for differentiation of fecal Escherichia coli from humans, poultry and wild birds. FEMS Microbiol Lett 277:98-106

21. Freitas DB, Reis MP, Lima-Bittencourt CI, Costa PS, Assis PS, Chartone-Souza E, Nascimento AM (2008) Genotypic and phenotypic diversity of Bacillus spp. isolated from steel plant waste. BMC Res Notes 1:92
22. Ryberg A, Olsson C, Ahrne S, Monstein HJ (2011) Comparison of (GTG) $)_{5}$-oligonucleotide and ribosomal intergenic transcribed spacer (ITS)-PCR for molecular typing of Klebsiella isolates. J Microbiol Methods 84:183-188

23. Svec P, Novakova D, Zackova L, Kukletova M, Sedlacek I (2008) Evaluation of (GTG) $)_{5}$-PCR for rapid identification of Streptococcus mutans. Antonie Van Leeuwenhoek 94:573-579 